Páipéar Taighde Teicniúil

Research Technical Paper

Credit conditions, macroprudential policy and house prices

Robert Kelly, Fergal McCann and Conor O’Toole 


\title{
Credit conditions, macroprudential policy and house prices
}

\author{
Robert Kelly $^{a}$, Fergal McCann ${ }^{b}$ and Conor O'Toole ${ }^{b *}$ \\ ${ }^{a}$ Monetary Policy Division, Central Bank of Ireland \\ ${ }^{b}$ Financial Stability Division, Central Bank of Ireland
}

December 2015

\begin{abstract}
We provide a micro-empirical link between the large literature on credit and house prices and the burgeoning literature on macroprudential policy. Using loan-level data on Irish mortgages originated between 2003 and 2010, we construct a measure of credit availability which varies at the borrower level as a function of income, wealth, age, interest rates and prevailing market conditions around Loan to Value ratios (LTV), Loan to Income ratios (LTI) and monthly Debt Service Ratios (DSR). We deploy a property-level house price model which shows that a ten per cent increase in credit available leads to an 1.5 per cent increase in the value of property purchased. Coefficients from this model are then used to fit values under scenarios of macroprudential restrictions on LTV, LTI and DSR on credit availability and house prices in Ireland for 2003 and 2006. Our results suggest that macroprudential limits would have had substantial impacts on house prices, and that both the level at which they are set and the timing of their introduction is a crucial determinant of their impact on housing values.
\end{abstract}

Keywords: Mortgages, credit availability, macroprudential policy, house prices.

*E-mail: robert.kelly@centralbank.ie; fergal.mccann@centralbank.ie; conor.otoole@centralbank.ie. We thank, in alphabetical order, Minhea Constantinescu, Christian Danne, Edward Gaffney, John Krainer, Terry O'Malley, Stefano Neri and Christian Schnittker for helpful discussions, along with seminar participants at the Central Bank of Ireland, participants at the ESRB workshop on "The dual relationship between the financial sector and the real economy: lessons for macroprudential oversight", participants at the Central Bank of Ireland workshop "Banking, credit and macroprudential policy: what can we learn from micro data?", and the European Banking Authority workshop on "Financial regulation and the real economy: a micro-prudential perspective". The views presented in this paper are those of the authors alone and do not represent the official views of the Central Bank of Ireland or the European System of Central Banks. Any remaining errors are our own. 


\section{Non Technical Summary}

The global financial crisis of 2007/2009 highlighted limitations in the ability of supervisors to manage financial sector risks on a systemic wide basis. In particular, the crisis highlighted the integral role of the housing market in driving financial cycles. To address these challenges, regulatory authorities have recently put a greater focus on the use of macro-prudential policy (MPP) instruments which are aimed at breaking the link between credit growth, house prices and banking sector instability as well as building bank and borrower resilience to financial shocks. In particular, macro-prudential tools specifically targeting the mortgage market such as restrictions on the Loan to Value (LTV), Loan to Income (LTI) or Debt Service (DSR) ratios of originated mortgages have become more widespread and were introduced in Ireland for new mortgage lending from early 2015.

Despite their increasingly commonplace existence in global regulatory toolkits, there is a dearth of evidence which tests the effectiveness of these limits. In this research, we use loan-level data on Irish mortgages to test how MPP restrictions would impact house prices through the credit available to households. Our methodology uses prevailing market conditions on the level of originating LTV, LTI and DSR available in a given quarter to construct three possible loan amounts for each borrower, commensurate with their income, deposit and age. We then estimate the potential credit available to a borrower as the smallest of these three loans. This approach in essence calculates, given a particular borrowers' characteristics, what is the maximum level of credit the bank would be willing to extend. This measure of credit available is then linked to house prices. We can then employ macroprudential limits on mortgage credit and link these changes to house prices through this framework.

A number of findings emerge. We first show initially that in Ireland between 2003 and 2010, the majority of borrowers had their credit availability determined by the prevailing LTI ratio, with extremely small numbers of borrowers being cut off along the LTV channel due to the existence of 100 per cent LTV mortgages. We find that macroprudential limits on LTI, LTV and DSR would have had substantial impacts on house prices in the short run. The results also indicate that both the level at which measures are set and the timing of their introduction is a crucial determinant of their impact on housing values.

We believe that our paper is the first to treat the relationship between MPP, mortgage credit and house prices at such a granular level of detail, and the first to quantitatively estimate the impact of MPP scenarios on house price paths. Further research is warranted on the general equilibrium effects that follow on from the introduction of an MPP, particularly relating to borrower exclusion, housing supply and the rental market. 


\section{Introduction}

Given the key role of the housing market in credit and asset price cycles, as well as the link between housing finance and the 2007-2009 global financial crisis (Brunnermeier, 2009; Duca et al., 2010, 2011a), regulatory authorities have recently put a greater focus on the use of macro-prudential instruments. Such macro-prudential policy (MPP) measures are aimed at breaking the link between credit growth, house prices and banking sector instability as well as building bank and borrower resilience to financial shocks (Kashyap et al., 2011; IMF, 2013). In particular, macro-prudential tools specifically targeting the mortgage market have become extremely common especially given the role played by the mortgage market in the recent global financial crisis (Elul et al., 2010; Mian and Sufi, 2009). As part of their overall financial stability toolkit, many countries have imposed restrictions on the Loan to Value (LTV) or Loan to Income (LTI) ratios of originated mortgages. ${ }^{1}$

While a large literature exists linking credit flows and house prices, ${ }^{2}$ a relatively recent literature has emerged attempting to measure the impact of specific MPP measures in the housing market, mainly using cross-country or single country macroeconomic data (Kuttner and Shim, 2013; Vandenbussche et al., 2015; Cerutti et al., 2015). The evidence suggests a tentative link between these MPP and house prices with a more conclusive finding on the impact of MPP on credit growth. However, a limitation of these papers is that the majority are at the aggregate level and rely on the use of average indicators in their identification strategy in cross country or single country models. In particular relating to LTI and LTV limits in the mortgage market, this approach may miss the complexity through which these limits impact borrower behaviour which can only be tested with adequate within-country borrower-specific variation. One exception is Igan and Kang (2011) who show, using survey data, that households were more likely to have dampened house price expectations and delayed house purchases in Korea after the introduction of macroprudential limits on LTV and LTI.

Given this gap in the literature, we use loan-level data on roughly two-thirds of the Irish mortgage market between 2003 and 2010 to provide a micro-empirical bridge between the literature on credit and house prices and the nascent literature on the impacts of macroprudential policy. Our aims in this paper are threefold. Firstly, we provide novel insights into the way in which credit conditions such as the LTV, LTI and DSR act to determine the credit available for a heterogeneous distribution of borrowers. We measure credit available in an innovative way at the loan level: for every individual borrower there are three potential mortgages that a bank will supply as a function of the borrowers' income, down-payment and age, combined with prevailing market limits on LTV, LTI and DSR. The

\footnotetext{
${ }^{1}$ See IMF (2013) for a review. The IMF Global Macroprudential Policy Database notes 46 countries with LTV limits and 36 countries with DTI limits.

${ }^{2}$ Related literature includes Duca et al. (2011b); Anundsen and Jansen (2013); Fitzpatrick and Mcquinn (2007); Lindner (2014); Gerlach and Peng (2005); Avouyi-Dovi et al. (2014).
} 
credit available to a borrower is then the minimum of the three mortgages calculated, consistent with the way in which a bank would arrive at a credit allocation decision in practice. This measurement of credit availability differs greatly to aggregate measures used in the existing literature (Duca et al., 2011b; Jansen and Krogh, 2011; Fernandez-Corugedo and Muellbauer, 2006) in terms of the granularity of what is being measured and the way in which borrower heterogeneity is directly captured.

Secondly, we use a reduced-form, loan-level house price model to link our measure of credit supply to house prices at the micro-level. This is the first study of which we are aware to use micro-data to link credit, macro-prudential instruments and house prices.

Thirdly, using the coefficients of our loan-level house price model, we trace through the impact of MPP regimes to house prices. Our set-up is extemely flexible in that the user can set levels of LTV, LTI and DSR at any level they wish, with the algorithm recalculating each borrower's credit availability as a function of three new mortgages. This differs greatly from aggregate studies on macroprudential housing instruments, which generally observe an average value for an instrument such as the LTV across the entire market. The framework then allows a change to MPP limits on LTV, LTI and DSR to impact house prices through two channels: directly through a reduction in credit available, and indirectly through the role that reduced regional house prices have on the down-payment available to previous-owners. We highlight two important factors that impact the magnitude of the effect of a set of MPP restrictions on house prices: (i) the stringency of the limits on LTV, LTI or DSR (ii) the point in the housing cycle at which the MPP is implemented.

As well as the aforementioned literature estimating the impact of MPP in aggregate empirical settings, our research is a complement to the burgeoning literature which tests the impact of macroprudential policy in an aggregate set-up through DSGE or structural econometric models (Akram, 2014; Bailliu et al., 2015; Clancy and Merola, 2014; Gerali et al., 2010; Kannan et al., 2012; Quint and Rabanal, 2014). These papers mainly enter macro-prudential policy into their set-up through aggregate credit growth, bank liabilities limits or the price of credit/external financing premium (see Brzoza-Brzezina and Kolasa (2013)). These models are not able to disentangle the impact of specific macro-prudential limits such LTI and LTV on credit availability and in turn on house prices. By estimating our model at the borrower level we can go beyond the aforementioned research and can trace through the impact of each of these limits simultaneously.

Where such macro-economic models have channeled specific LTV limits (Brzoza-Brzezina, 2014; Brzoza-Brzezina et al., 2015; Rubio and Carrasco-Gallego, 2014), these are entered as the average LTV. Given that the average of observed LTV is in fact the intersection of both the supply of credit and the borrowers' demand for leverage, such measures do not cleanly identify pure credit supply impacts. Additionally where LTI, LTV or DSR limits are in fact simultaneously imposed by macro-prudential authorities these macro-studies cannot specifically test which measure has the greater impact on credit 
and house prices. Our measure, by focusing on credit availability and allowing each borrower to be limited by one channel, can provide additional insight to existing research.

Our research is also linked to two further literatures. First, our work complements studies at the aggregate level which have studied the link between MPP and financial outcomes such as credit growth, mortgage delinquency, leverage and indebtedness, without looking specifically at the impact on house prices (Wong et al., 2011; Claessens et al., 2013; International Monetary Fund, 2011; Cerutti et al., 2015; Jacome and Mitra, 2015). Second, we build on recent studies that exploit sub-national data and provide evidence of a causal effect of liberalised credit on house prices (Favara and Imbs, 2015; Di Maggio and Kermani, 2014; Adelino et al., 2012; Labonne and Welter-Nicol, 2015; Anenberg et al., 2015) by providing a loan-level estimate of the credit-house price elasticity.

A number of findings emerge. Our estimates suggest that during the Irish housing boom, the majority (70-80 per cent) of borrowers had their credit available determined along the loan-to-income channel, with 20-30 per cent being cut off by monthly debt service ratio (DSR) limits, and only a small amount being cut off by LTV limits. When these measures are combined into our indicator of credit availability and this is included in a log-log house price specification, the elasticity of house prices with respect to credit availability is estimated in our baseline model at 15 per cent, which is extremely close to estimates from Favara and Imbs (2015), who provide the only published estimate of a cleanly-identified causal effect of credit supply on house prices. Across a range of robustness tests, we estimate the elasticity to always be within a range of 12 to 27 per cent. Our micro-level house price model also estimates that a ten per cent increase in income increases house prices by between 2.1 and 2.6 per cent while a ten per cent increase in wealth increases house prices by $2.4-2.5$ per cent.

To trace the impact of macro-prudential policy on house prices, we impose two separate regimes which are drawn from the range of international parameterisations of such measures. ${ }^{3}$ We then apply these regimes at periods of tighter and looser market conditions for general credit conditions and estimate the new fitted house price distribution under these scenarios. Given that our micro-data framework cannot incorporate general equilibrium housing market effects such as changes to housing supply, impacts on the rental market and the entry of Buy-to-Let investors, we restrict our scenario re-fitting of house prices to the short-run. We do so by starting with observed average house prices in 2003 and 2006, and estimating the cumulative one-year effect of the introduction of two sample MPP regimes. The model estimates that the switching on of Regime 1 (75 LTV, 4 LTI and 37 DSR) in 2003 would have led to a fall in average house prices from observed levels of 6.4 per cent after four quarters. During the high-growth period of 2006, this MPP regime would have led to one-year falls of 12.1 per cent. Our less restrictive MPP regime, Regime 2 (85 LTV, 4.5 LTI and 45 DSR) is estimated to have a one-year effect of just over 1 per cent when switched on in 2003, with this effect rising to 8.7 per

\footnotetext{
${ }^{3}$ See Jacome and Mitra (2015) for an overview.
} 
cent when switched on in 2006. We also present sensitivities across values of LTI and LTV to provide further insight into the impact on house prices of different policy calibrations.

From a policy perspective, our results provide insight for regulators attempting to understand the calibration of MPP measures in the mortgage market. First, the specific parameterisation as well as the instrument matters. We find that LTI is in general the more binding tool relative to LTV and DSR. However, this balance reverses as tighter caps on LTV and DSR are introduced. Second, the differential between current market credit conditions and the stringency of proposed measures is important. Our results indicate that MPP measures have a smaller impact when market credit conditions are tighter. This suggest policymakers such take into account the point in the credit cycle when calibrating such instruments.

The paper is structured as follows: Section 2 discusses data sources and measurement of credit supply; Section 4 describes the impact of macroprudential policy on borrowers' available credit supply; Section 3 presents our house price model, Section 4 describes the introduction of MPP regimes and re-fitting of the short-run house price distribution; Section 5 concludes.

\section{Data}

The data used come from the Central Bank of Ireland's Loan Level Data (LLD). These files contain information on all loans issued by Irish banks participating in the 2011 Financial Measures Programme (FMP). In the case of the Irish residential mortgage market, these four lenders account for roughly two thirds of the total market, making this a particularly rich source of data. ${ }^{4}$ The data have been explained in detail by Kennedy and McIndoe-Calder (2012). Information is provided on inter alia current mortgage balance, bank, current interest rate, origination and current interest rate type, origination and maturity dates, original installment, current loan to value ratio (LTV), and First Time Buyer status (FTB). Certain characteristics of the borrower are also reported in the data, such as marital status, geographic location, employment group, income and whether the application is joint or single assessment. Crucially from the point of view of this study, the valuation of the property at loan origination is included which provides a borrower-specific house purchase price. These variables are all collected at the mortgage origination date and these data can be combined with the originating mortgage criteria to provide a dataset linking indicators of LTV, LTI and Debt-Service-Ratio (DSR) to house prices.

Given data availability, our sample runs from January 2003 to December 2010. A number of

\footnotetext{
${ }^{4}$ The four lenders are Allied Irish Banks, Bank of Ireland, the Educational Building Society (EBS) and Permanent TSB (PTSB). EBS has subsequently been merged into the Allied Irish Banks group as part of the FMP programme. PTSB was previously known as Irish Life and Permanent.
} 
inclusion criteria are applied to the data. Firstly, only primary dwelling (often referred to as owneroccupied) mortgages are considered. Investor or Buy-to-Let (BTL) mortgages are omitted from the data set, as the originating credit decision of the lender, as well as the type of macro-prudential limit that a regulator would set, are distinct across the PDH and BTL segments of the mortgage market. ${ }^{5}$ We also restrict loans to those that were for the purpose of home purchase, removing those used for equity release or for refinancing. This restricts the sample to mortgages underlying transactions of properties between two parties. Finally we control for outliers by removing the 99th percentile in our key variables of interest.

The final baseline regression sample consists of 188,405 property purchases. Figure 1 plots the number of property purchases per quarter in the data. The data are highly seasonal, with a visible dip in transaction numbers in the first quarter of each year. Consistent with aggregate data on the Irish mortgage market, activity is at its most intense in our data set in 2005, 2006, and 2007.

Figure 1: Number of transactions per quarter, regression sample 2003-2010

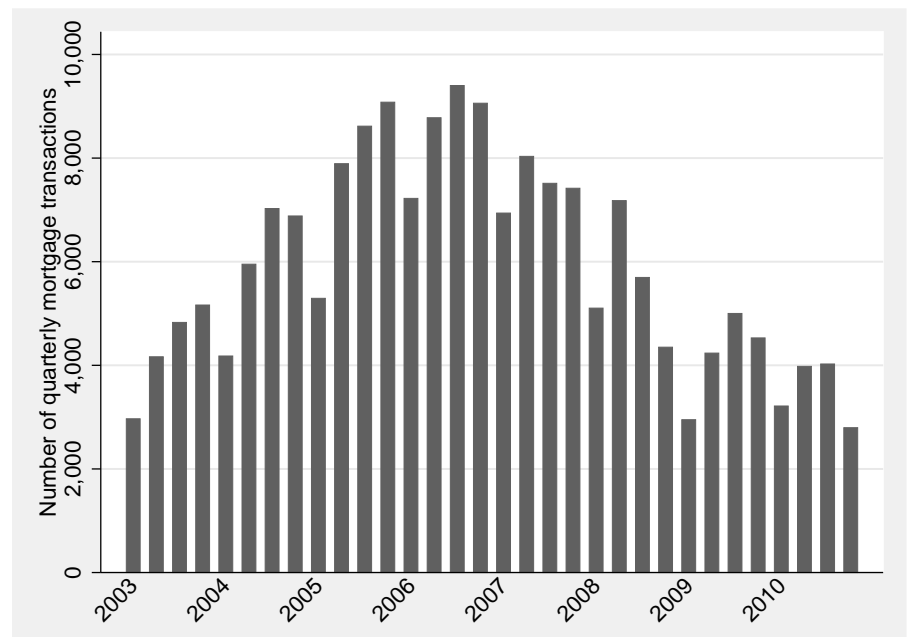

Source: Central Bank of Ireland Loan Level Data

\subsection{Construction of measure of available credit}

Credit conditions have previously been measured at the aggregate level in studies such as FernandezCorugedo and Muellbauer (2006) which uses aggregate proportions of high-LTV and high-LTI loans,

\footnotetext{
${ }^{5}$ Internationally there is a developing trend towards the differential treatment of buy-to-let investors from a macro-prudential perspective. In January, 2015 Ireland announced a differential LTV ceiling for buy-to-lets while New Zealand has also brought in investor-specific limitations. See national Central Bank websites for more detail.
} 
the average first time buyer LTV index for the USA of Duca et al. (2011b), and the Norwegian index of Jansen and Krogh (2011). McCarthy and McQuinn (2013) provide an alternative for Ireland by calculating the term, LTV and DSR chosen by borrowers at origination and showing that these levels are heterogeneous across borrower groups. Their study also backs out an aggregate index from regressions using micro-data.

Our approach departs from the extant literature: rather than constructing an index based on aggregate averages or observed drawdown values, we calculate the maximum amount of credit that each borrower could access when applying for a loan (credit available, $C A$ ). Our measurement has two key characteristics: (i) it differs for every borrower as a function both of borrower characteristics and prevailing bank lending conditions (ii) it is a function of originating supply-side credit conditions that can be limited by macroprudential policy, namely the LTI, LTV and DSR. These features make our measure of $C A$ well-suited to incorporating the impact of macroprudential limits. The approach is similar in spirit to that of Anenberg et al. (2015) who apply a frontier estimation approach used frequently in the industrial organizational literature to estimate borrower-specific loan amounts available, but who do not incorporate credit conditions around LTV, LTI or DSR into their analysis.

We construct $C A$ so that it can directly incorporate three distinct types of credit condition by allowing all borrowers to have three potential loans. We reiterate that it is crucial to distinguish these loans, which are measures of the supply of credit available to each borrower, from the observed loan amount that was actually borrowed, as the latter is a function of both supply and demand for credit. The three loans associated with each borrower are outlined in turn:

$$
\operatorname{Loan}_{L T V}=\frac{\text { Deposit }}{100-L T V_{M a x}}-\text { Deposit }
$$

$\operatorname{Loan}_{L T V}$ is the loan that is consistent with the deposit or down-payment available to the borrower, combined with the maximum LTV that banks are offering on the market at the time of mortgage origination. This measure of credit supply, $L T V_{M a x}$, is calculated as the 98th percentile of observed originating LTVs in the market in a given quarter. The evolution of this metric from 2003q1 to 2010q4 is depicted in Figure 2. The data suggest that down-payment constraints were essentially eliminated during most of the sample period in Ireland, with the advent of 100 per cent LTV mortgages. Under such a regime, there is an infinite amount of credit available to borrowers along this channel.

$$
\operatorname{Loan}_{L T I}=\text { Income }^{*} L T I_{M a x}
$$

$\operatorname{Loan}_{L T I}$ is the loan that is consistent with the borrower's income at origination, combined with the maximum LTI that banks were offering in the market at that point in time. We use total household gross income, as this is the measure that is used by Irish banks when calculating the LTI. Figure 3 
Figure 2: 98th percentile LTVs, observed quarterly mortgage data 2003-2010

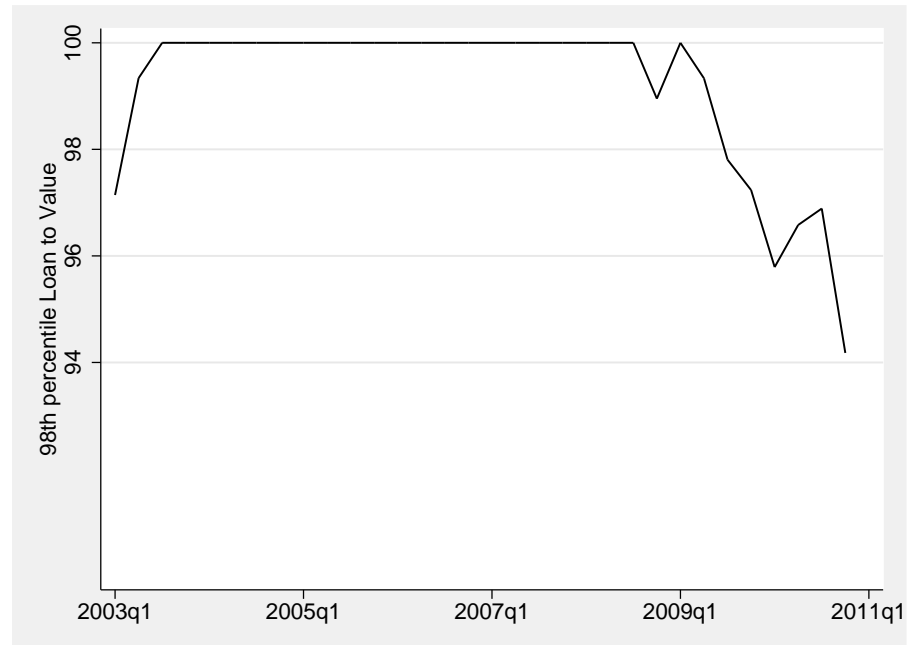

Source: Central Bank of Ireland Loan Level Data, authors' calculations

highlights clearly how credit conditions loosened along this channel between 2003 and 2007, with the available LTI limit going from just over 5 to 6.5. By end-2010, this measure had fallen to circa 5.5.

Figure 3: 98th percentile LTIs, observed quarterly mortgage data 2003-2010

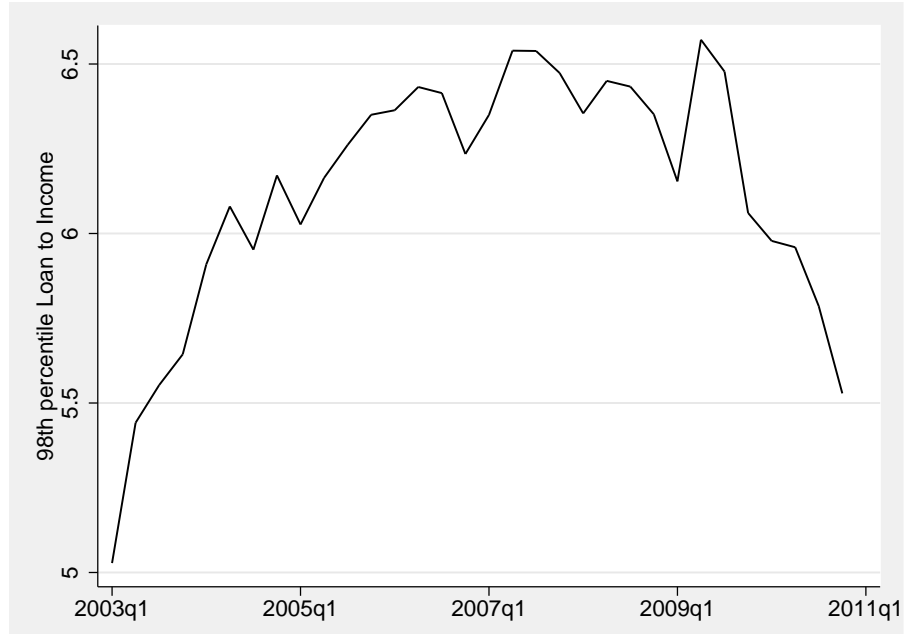

Source: Central Bank of Ireland Loan Level Data, authors' calculations

$$
\operatorname{Loan}_{D S R}=\operatorname{RepayMax}_{i t} * \frac{1-(1+r)^{-T E R M_{i}}}{r}
$$


$\operatorname{Loan}_{D S R}$ is the loan consistent with the maximum monthly repayment that a bank will sanction at time $t$. This repayment, RepayMaxit is the product of borrower $i$ 's net monthly income and the monthly maximum DSR being offered by banks at time $t$. The available DSR, calculated as the 98th percentile of observed originating DSRs in the data, is pictured in Figure 5. The stark loosening of credit conditions along this channel is clearly visible in the picture, with our measure of DSR availability rising from 35 per cent of net monthly income to 50 per cent by late 2008. By 2010, the ratio had returned to 2003 levels of 30 to 35 per cent, with part of the sharp decline being driven by falls in the ECB main refinancing operation rate during late 2008 and early 2009.

Along with RepayMaxit, the calculation of $\operatorname{Loan}_{D S R}$ requires information on the interest rate being charged at time $t$ and the maximum mortgage term that can be attained by borrower $i$. Equation 3 is a modification of a standard annuity formula to transform a monthly repayment into a loan balance amount. $r$ is the interest rate on the chosen mortgage contract at origination. ${ }^{6} T E R M_{i}$ is calculated as the difference between the age of the borrower and the maximum age at which banks are willing to

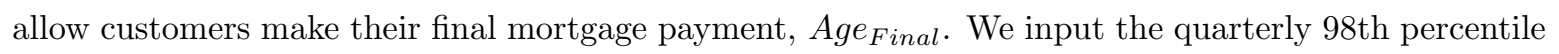

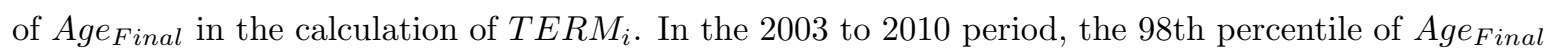
remains between 70 and 75 years, with an increasing trend between 2003 and 2007 as would be expected during a period of loosening credit conditions.

$$
C A=\operatorname{Min}\left(\operatorname{Loan}_{L T V}, \operatorname{Loan}_{L T I}, \operatorname{Loan}_{D S R}\right)
$$

Armed with three potential loans per borrower, each of which is a function both of a key borrower characteristic and a prevailing supply-side credit condition, $C A$ is calculated simply as the minimum of the three loan sizes. As an illustration, if a borrower has a deposit of $€ 5,000$ and the prevailing available Loan to Value ratio is 90 per cent, that borrower will not get a mortgage larger than $€ 45,000$ (i.e. the deposit of $€ 5,000$ comprises 10 per cent of the purchase of a property worth $€ 50,000$ ), regardless of income, age, the prevailing interest rate, or credit conditions along the LTI and DSR channels.

Figure 6 plots the share of all mortgages originated in a given quarter that have $C A$ determined by each of the three credit conditions LTV, LTI and DSR. The first important feature to note is that, in a period where the available LTV has reached 100 per cent, no borrower is deemed to be cut off by the LTV channel, as in theory all borrowers can access a loan amount of infinity along this channel. The salience of the LTI channel is clear from this graph: up to 2007, 70 to 80 per cent of borrowers had a

\footnotetext{
${ }^{6}$ Measured for standard variable rate (SVR) mortgages using the advertised new lending rates for SVR mortgages by bank and quarter provided by the Central Bank of Ireland Statistics division. For tracker loans, we calculate a margin above the ECB rate using the differential between the interest rate observed in the data and the ECB rate at December 2013, and then assuming this margin is constant through time to apply it to the ECB rate at the point of mortgage origination. For the small number of fixed rate loans in the data, we make the simplifying assumption that the originating interest rate equaled the SVR rate.
} 
Figure 4: 98th percentile implied age at mortgage maturity, observed quarterly mortgage data 2003-2010

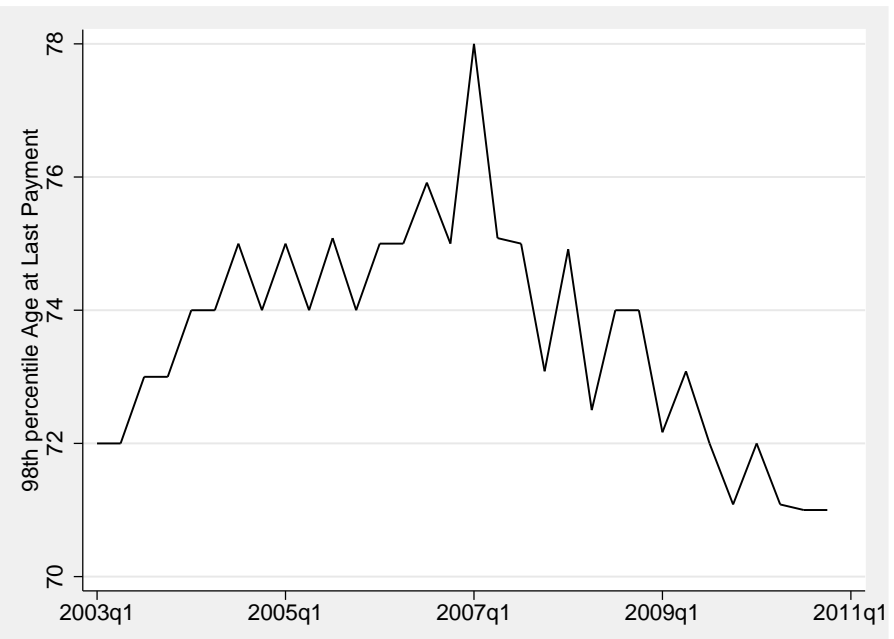

Source: Central Bank of Ireland Loan Level Data, authors' calculations

Figure 5: 98th percentile DSRs, observed quarterly mortgage data 2003-2010

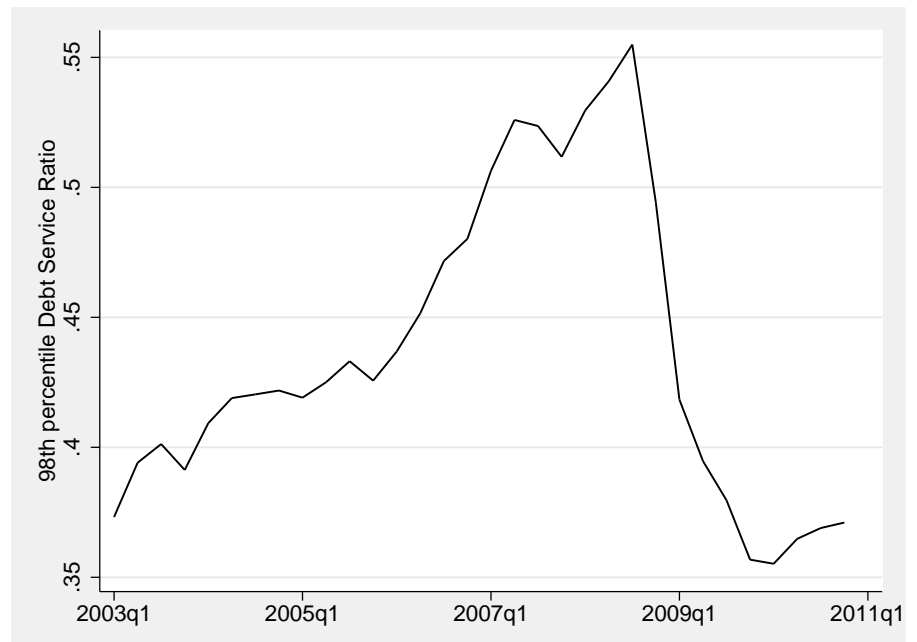

Source: Central Bank of Ireland Loan Level Data, authors' calculations

$C A$ that was determined on the LTI channel. Borrowers who have their $C A$ determined by the DSR are generally borrowers who apply for mortgages at an older age, which leaves them with a shorter maximum available mortgage term, meaning that for any given monthly payment amount, they can access a smaller total loan amount. Consistent with the prevalence of 100 per cent LTV mortgages, 
for the majority of our sample period, there are no borrowers restricted along the LTV channel.

Figure 6: Which prevailing market condition determines credit availability? Quarterly market shares 2003 to 2010.

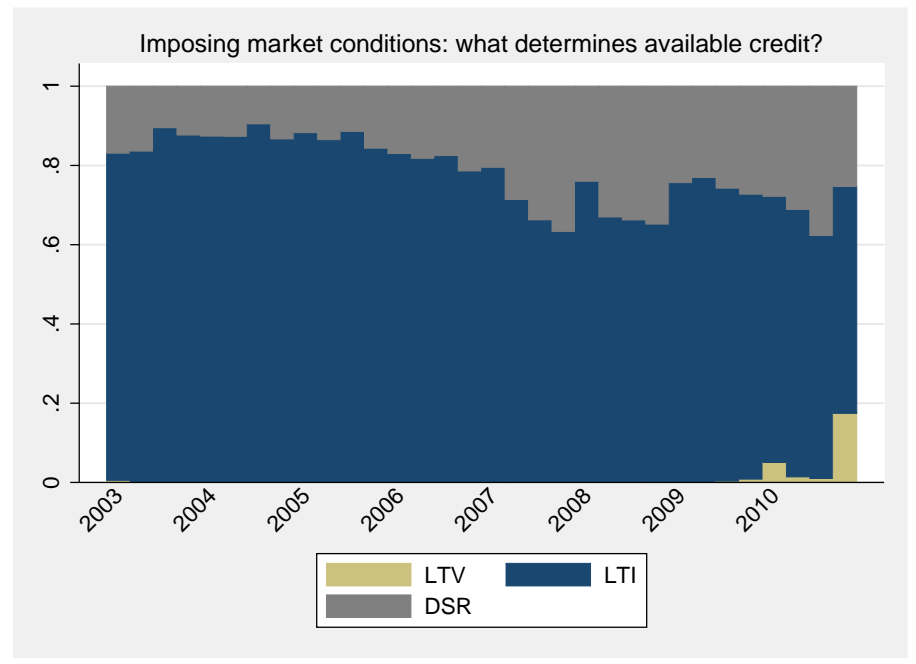

Source: Central Bank of Ireland Loan Level Data, authors' calculations

One innovation of our research is an attempt to ensure that $C A$ is constructed using the levels of LTV, LTI and DSR that were made available by lenders, i.e. $C A$ represents supply-side availability of credit. We argue that by taking the 98th percentile of observed originating LTV, LTI or DSR in the market in a given quarter, we are able to proxy the credit available to any borrower, should they have wished to access such a large volume of credit. ${ }^{7}$ Taking the right tail of the observed distribution of LTI, LTV or DSR is a valid proxy for the amount available to any borrower if one accepts the assumption that in every time period there is a tail of borrowers with an insatiable appetite for credit, who will always take a higher LTV, LTI or DSR if a bank is willing to offer it. If this group of borrowers exists, the right tail of observed LTV, LTI or DSR values represents an approximation of the point at which banks' credit supply restricts the amount of credit available. A very similar line of thought is invoked by Anenberg et al. (2015) in estimating a "loan frontier" which approximates the supply-side availability of credit using US mortgage data. The existence of borrowers who will go to the maximum amount available is confirmed in the Canadian mortgage market by Allen et al. (2015) who show that, upon the move from 10 per cent to 5 per cent minimum downpayments in 2003, up to one third of affected mortgage borrowers moved to this new minimum downpayment amount, with a subsequent

\footnotetext{
${ }^{7}$ We take the 98 th percentile rather than the maximum or 99th percentile of observed LTV, LTI and DSR as our measure of credit supply in order to create a smoother series which is less prone to data errors, and outlier credit allocations which may have been sanctioned by a local loan officer due to exceptional circumstances such as a parental guarantee or high observed family wealth.
} 
increase in the average household debt to equity ratio from 8 to 14 .

The imposition of a market-wide 98th percentile LTV, LTI or DSR in the calculation of $C A$ for all borrowers may seem crude, given that lender may impose differential lending standards in different market segments. The experience in Ireland suggests that this is less of a concern for this study than those in other jurisdications: anecdotal evidence in Ireland suggests that lenders offer mortgages as standard products, whereby once any borrower is deemed credit-worthy, they can access loans at the same level of LTV, LTI or DSR. As a robustness check to our empirical house price model, we allow 98th percentile values to be calculated within specific subgroups of the market, to allow for the fact that lenders may differentiate the level of LTV, LTI or DSR at which they lend as a function of borrower characteristics.

\section{House price regression model}

\subsection{Empirical approach}

A key aim of our research is to estimate the link between credit availability and house prices which will allow us to evaluate the impact of macro-prudential limits in the mortgage market. By running a regression model at the property level where $C A$ is shown to have an effect on house prices, we can then trace a link through from a change in macroprudential policy rules to a new calculation of $C A$ for every mortgage borrower to estimates of fitted house prices under the policy regime. Our construction of $C A$ as incorporating LTI, LTV and DSR means that macroprudential rules can be easily mapped to borrower-specific credit shocks. To test the link between credit and house prices, we specify a reduced form model of house prices at the loan level using the following:

$$
H P_{i t}=f\left(C A_{i t}, \text { Income }_{i t}, \text { Wealth }_{i t}, \text { Bank }_{i t}, \text { PropertyType }_{i t}, \lambda_{R T}, \mathbf{D}_{\mathbf{i t}}\right)
$$

Where the dependent variable $H P_{i t}$ is the euro price of the house sold, $C A$ is our measure of credit availability, Income is measured as the total income of borrowers filling in the mortgage application, Wealth is proxied by the deposit posted by the borrower, Bank is a dummy for the four banks in our sample and PropertyType takes eight values for apartment, small houses (semi-detached or terraced), large detached houses, and unclassified houses in both Dublin and outside Dublin. $\mathbf{D}_{\mathbf{i t}}$ are additional demographic characteristics that we include as controls and are defined in each regression specification.

$\lambda_{R T}$ is a vector of 256 region*time control variables. These dummy variables will capture all local macroeconomic dynamics that would be expected to impact the housing market in a given quarter, including any feedback between house price developments and banks' lending standards. We do not believe it plausible that the price paid by an individual house purchaser should impact banks' 
lending standards vis-"a-vis that particular homeowner, once we are controlling for aggregate lending standards. Therefore, we argue that the $\lambda_{R T}$ purge our loan-level estimates of the impact of credit availability on house purchase prices from the reverse causality concerns that typically arise when estimating the effect of credit on house prices using aggregate data.

In our data, we do not observe the total wealth of the borrower so instead must rely on the posted value of the deposit as a proxy. Of concern is that down-payments are at the discretion of the borrower. A borrower may have wealth available of $€ 100,000$, but may have a preference for lower leverage or for continuation of savings, and therefore holds back a significant portion of her wealth and posts a deposit of $€ 50,000$. Our model above would in this case underestimate both Wealth and $\operatorname{Loan}_{L T V}$, given that it is calculated based on the value of $€ 50,000$ and the prevailing LTV limits. We make an effort to adjust the deposit amount to account for the fact that borrowers vary in their risk and leverage appetite, and post down-payments which are some fraction of the true wealth available for house purchase. Our approach is to take groups of households that are unique in their First Time Buyer status (two categories), income quintile within originating year (5 categories), group of originating year (3 categories), marital status (3 categories) and Dublin status (2 categories). Within these distinct groups, we take the average ratio of deposit to income $\left(\frac{D}{I}\right)$. Wealth is then calculated as

$$
\text { Wealth }_{i t}=\operatorname{Max}\left(\text { Income }_{i t}^{*} \frac{D}{I}, \text { Deposit }_{i t}\right)
$$

Table 1 provides summary statistics for the above explanatory variables. The average house price in our sample is circa $€ 314,000$ with a standard deviation of $€ 127,000$. Average credit availability in our data is $€ 367,000$. As expected, this is higher than the average loan size in the data and reflects the value of credit the bank would have been willing to extend given the borrowers' characteristics. Mean income is approximately $€ 61,000$ while average posted deposit (our wealth proxy) is $€ 133,000$. On the composition of borrowers in our sample, average borrower age is 35, 44 per cent are first time buyers and 84 per cent are employee's with the remainder self-employed. Of the properties purchased in our data, 30 per cent are detached houses outside Dublin, while 26 per cent are semi-detached or terraced houses outside Dublin. In total, Dublin transactions account for 25.36 per cent of the purchases in the data set. 
Table 1: Summary statistics

\begin{tabular}{lrrr}
\hline \multicolumn{1}{c}{ Variable } & Obs & \multicolumn{1}{c}{ Mean } & St. Dev. \\
\hline House Price & 188,405 & 314,148 & 127,130 \\
\hline In & 188,405 & 367,837 & 154,996 \\
Income & 188,405 & 61,307 & 26,985 \\
Deposit & 188,405 & 111,745 & 106,469 \\
Wealth for Down-Payment & 188,405 & 133,199 & 97,899 \\
Borrower Age (years) & 188,405 & 35.037 & 7.971 \\
Sample shares for categorical variables & \\
\hline Bank 1 & 188,405 & $17 \%$ & \\
Bank 2 & 188,405 & $26 \%$ & \\
Bank 3 & 188,405 & $24 \%$ & \\
Bank 4 & 188,405 & $34 \%$ & \\
\hline Non-Dublin Apartment & 188,405 & $2.09 \%$ & \\
Non-Dublin House & 188,405 & $29.52 \%$ & \\
Non-Dublin Other & 188,405 & $16.69 \%$ & \\
Non-Dublin Terrace/Semi & 188,405 & $26.33 \%$ & \\
Dublin Apartment & 188,405 & $4.55 \%$ & \\
Dublin House & 188,405 & $1.36 \%$ & \\
Dublin Other & 188,405 & $7.6 \%$ & \\
Dublin Terrace/Semi & 188,405 & $11.85 \%$ & \\
\hline Second or Subsequent Buyer & 171,971 & $55.1 \%$ & \\
First Time Buyer & 171,971 & $44.9 \%$ & \\
\hline Employed, Salary & 161,346 & $84.8 \%$ & \\
Self Employed & 161,346 & $15.2 \%$ & \\
\hline Married & 185,442 & $44.6 \%$ & \\
Separated/Divorced & 185,442 & $4.7 \%$ & \\
Single & 185,442 & $50.7 \%$ & \\
\hline
\end{tabular}




\subsection{Estimation results}

Results from our baseline model are reported in Table 2. The coefficient on $C A$ is extremely stable across columns (1) and (2), where firstly the down-payment posted is used to proxy wealth, and secondly our adjusted measure is used. A one-euro increase in $C A$ is associated with an increase in the value of house purchased of 20.5 to 21.8 cents. Older borrowers purchase less expensive houses, ceteris paribus. One additional year in age is associated with a fall in house value of $€ 850-1,070$. Our controls for property types have important explanatory power. Relative to Dublin detached houses, a nonDublin apartment sells on average for more than $€ 100,000$ less. The smallest coefficient, in absolute value terms, is for Dublin semi-detached and terraced houses, suggesting that this is the second most valuable market segment in Ireland during the sample period.

Column (3) of Table 2 runs a log-log specification where $C A$, income and wealth are all entered in logarithmic form. The coefficients are thus interpretable as elasticities, with a 10 per cent increase in $C A$ estimated to lead to a 1.5 per cent increase in $H P$. This elasticity estimate is strikingly close to those estimated in Favara and Imbs (2015), who provide estimates of the elasticity of house prices to credit supply of between .12 and .16. Our estimates of the elasticity of $H P$ to income and wealth are .21 and .24 , respectively.

In Table 3, we examine the robustness of our findings on $C A$, Wealth and income to the inclusion of additional control variables at the loan and borrower level. In each model (1) to (4), the sample size is smaller than that in model (1) due to missing values for some of the additional explanatory variables. We introduce a dummy variable for First Time Buyers, self-employed borrowers and a threecategory marital status variable (single, married or separated/divorced) in combinations. Across all four models, the range of estimates for $C A$ is between .2 and .27 , which does represent an increase from the baseline model. The effects of income and wealth are in a very similar range in Table 3 to those estimated in Table 2.

Finally we test the robustness of our model to the way in which $C A$ is calculated. In the baseline model, $C A$ is estimated using the 98th percentile LTV, LTI and DSR among observed mortgages in any given quarter. However, it may be that lenders systematically make credit available using differing degrees of risk aversion in different market segments. To directly test whether such behaviour has an impact on our results, we re-calculate $C A$ by allowing 98 th percentile values to be calculated both within-quarter and within-group. We define four separate robustness tests based on four groups:

1. Bank (four groups)

2. First Time Buyer status (2 groups)

3. Dublin versus rest of country (2 groups) 
Table 2: Baseline model 2003 - 2010; OLS.

\begin{tabular}{|c|c|c|c|}
\hline & Level & Level & $\log$ \\
\hline \multirow[t]{2}{*}{ Credit Available } & $0.205^{* * *}$ & $0.218^{* * *}$ & \\
\hline & $(0.00692)$ & $(0.00732)$ & \\
\hline \multirow{2}{*}{ Income } & $0.772^{* * *}$ & $0.575^{* * *}$ & \\
\hline & $(0.0400)$ & $(0.0423)$ & \\
\hline \multirow[t]{2}{*}{ Deposit } & $0.727^{* * *}$ & & \\
\hline & $(0.00197)$ & & \\
\hline \multirow[t]{2}{*}{ Borrower Age } & $-882.5^{* * *}$ & $-1070.6^{* * *}$ & $-0.00357^{* * *}$ \\
\hline & $(22.19)$ & $(23.88)$ & $(0.0000901)$ \\
\hline \multirow{2}{*}{ Wealth for Down-Payment } & & $0.761^{* * *}$ & \\
\hline & & $(0.00221)$ & \\
\hline \multirow[t]{2}{*}{ Log Credit Available } & & & $0.155^{* * *}$ \\
\hline & & & $(0.00956)$ \\
\hline \multirow[t]{2}{*}{ Log Income } & & & $0.215^{* * *}$ \\
\hline & & & $(0.00922)$ \\
\hline \multirow[t]{2}{*}{ Log Wealth for Down-Payment } & & & $0.246^{* * *}$ \\
\hline & & & $(0.000851)$ \\
\hline \multicolumn{4}{|c|}{ Reference category: Dublin Houses } \\
\hline \multirow[t]{2}{*}{ Non-Dublin Apartment } & $-107636.5^{* * *}$ & $-116527.6^{* * *}$ & $-0.511^{* * *}$ \\
\hline & $(4793.4)$ & $(5241.9)$ & $(0.0229)$ \\
\hline \multirow[t]{2}{*}{ Non-Dublin House } & $-90242.7^{* * *}$ & $-91174.4^{* * *}$ & $-0.382^{* * *}$ \\
\hline & $(4710.7)$ & $(5151.1)$ & $(0.0226)$ \\
\hline \multirow[t]{2}{*}{ Non-Dublin Other } & $-80508.9^{* * *}$ & $-82804.3^{* * *}$ & $-0.384^{* * *}$ \\
\hline & $(5109.9)$ & $(5563.8)$ & $(0.0235)$ \\
\hline \multirow[t]{2}{*}{ Non-Dublin Terrace/Semi } & $-102326.7^{* * *}$ & $-109876.6^{* * *}$ & $-0.481^{* * *}$ \\
\hline & $(4718.4)$ & $(5159.6)$ & $(0.0226)$ \\
\hline \multirow[t]{2}{*}{ Dublin Apartment } & $-48827.4^{* * *}$ & $-50206.0^{* * *}$ & $-0.138^{* * *}$ \\
\hline & $(1966.5)$ & $(2048.8)$ & $(0.00505)$ \\
\hline \multirow[t]{2}{*}{ Dublin Other } & $-34237.3^{* * *}$ & $-32924.8^{* * *}$ & $-0.0780^{* * *}$ \\
\hline & $(2726.5)$ & $(2853.4)$ & $(0.00783)$ \\
\hline \multirow[t]{2}{*}{ Dublin Terrace/Semi } & $-36789.2^{* * *}$ & $-38972.1^{* * *}$ & $-0.0964^{* * *}$ \\
\hline & $(1885.8)$ & $(1946.3)$ & $(0.00460)$ \\
\hline $\mathrm{N}$ & 188,405 & 188,405 & 188,405 \\
\hline$R^{2}$ & 0.753 & 0.725 & 0.666 \\
\hline 4 Bank dummies? & YES & YES & YES \\
\hline 256 Region*Time dummies? & YES & YES & YES \\
\hline
\end{tabular}


Table 3: Robustness: iterative addition of explanatory variables

\begin{tabular}{lrrrr}
\hline \hline & \multicolumn{1}{c}{$(1)$} & \multicolumn{1}{c}{$(2)$} & \multicolumn{1}{c}{$(3)$} & \multicolumn{1}{c}{$(4)$} \\
\hline Log Credit Available & $0.2029^{* * *}$ & $0.2366^{* * *}$ & $0.2566^{* * *}$ & $0.2723^{* * *}$ \\
& $(0.0111)$ & $(0.0113)$ & $(0.0101)$ & $(0.0114)$ \\
Log Income & $0.1865^{* * *}$ & $0.1590^{* * *}$ & $0.1461^{* * *}$ & $0.1378^{* * *}$ \\
& $(0.0107)$ & $(0.0109)$ & $(0.0097)$ & $(0.0110)$ \\
Log Wealth for Down-Payment & $0.2587^{* * *}$ & $0.2879^{* * *}$ & $0.3007^{* * *}$ & $0.3006^{* * *}$ \\
& $(0.0009)$ & $(0.0011)$ & $(0.0010)$ & $(0.0011)$ \\
Borrower Age & $-0.0023^{* * *}$ & $-0.0022^{* * *}$ & $-0.0010^{* * *}$ & $-0.0009^{* * *}$ \\
& $(0.0001)$ & $(0.0001)$ & $(0.0001)$ & $(0.0001)$ \\
Reference: Previous-owners & & & & \\
FTB & & $0.0913^{* * *}$ & $0.0807^{* * *}$ & $0.0840^{* * *}$ \\
& & $(0.0016)$ & $(0.0015)$ & $(0.0016)$ \\
Reference: Salaried & & & & \\
Self-Employed & $0.0242^{* * *}$ & $0.0245^{* * *}$ & & $0.0230^{* * *}$ \\
Reference: Married & $(0.0020)$ & $(0.0020)$ & & $(0.0020)$ \\
Separated/Divorced & & & & \\
& $-0.0161^{* * *}$ & & $-0.0070^{* *}$ & $-0.0065^{* *}$ \\
Single & $(0.0029)$ & & $(0.0027)$ & $(0.0029)$ \\
& $0.0648^{* * *}$ & & $0.0641^{* * *}$ & $0.0650^{* * *}$ \\
$N$ & $(0.0013)$ & & $(0.0013)$ & $(0.0014)$ \\
$R^{2}$ & 171971 & 161346 & 185442 & 160115 \\
\hline \hline
\end{tabular}

Dependent variable in all specifications is the natural log of property purchase price.

8 hedonic property type, 256 Region* Quarter, 4 bank dummies included in all models

Robust standard errors in parentheses

${ }^{*} p<.1,{ }^{* *} p<.05,{ }^{* * *} p<.01$ 
Table 4: Robustness: Credit Conditions varying by sub-group

\begin{tabular}{lcccc}
\hline \hline & $(1)$ & $(2)$ & $(3)$ & $(4)$ \\
Credit condition varies by: & Bank & Dublin & FTB & Property Type \\
\hline Log $C A$ & $0.124^{* * *}$ & $0.157^{* * *}$ & $0.238^{* * *}$ & $0.175^{* * *}$ \\
& $(0.00741)$ & $(0.00942)$ & $(0.00926)$ & $(0.00799)$ \\
Log Income & $0.246^{* * *}$ & $0.214^{* * *}$ & $0.138^{* * *}$ & $0.197^{* * *}$ \\
& $(0.00714)$ & $(0.00905)$ & $(0.00882)$ & $(0.00771)$ \\
Log Wealth for Down-Payment & $0.246^{* * *}$ & $0.246^{* * *}$ & $0.247^{* * *}$ & $0.246^{* * *}$ \\
& $(0.000850)$ & $(0.000851)$ & $(0.000849)$ & $(0.000851)$ \\
Borrower Age & $-0.00376^{* * *}$ & $-0.00352^{* * *}$ & $-0.00308^{* * *}$ & $-0.00347^{* * *}$ \\
& $(0.0000841)$ & $(0.0000907)$ & $(0.0000894)$ & $(0.0000853)$ \\
\hline Observations & 188405 & 188405 & 188405 & 188405 \\
$R^{2}$ & 0.666 & 0.666 & 0.666 & 0.666 \\
\hline \hline
\end{tabular}

Dependent variable in all specifications is the natural log of property purchase price.

256 Region* Time dummies, 8 hedonic property dummies and 4 bank dummies included in all models.

Standard errors in parentheses

${ }^{*} p<.1,{ }^{* *} p<.05,{ }^{* * *} p<.01$

\section{Property type (4 groups)}

In each case (1) to (4), the 98th percentile of LTV, LTI and DSR is calculated, within-group, withinquarter. The values for each within-group credit condition are reported in the Appendix in Figures A.1, A.2 and A.3. Some intuitive differences are revealed, for example the looser credit conditions among First-Time Buyers and within the Dublin housing market. For reasons of confidentiality, we cannot report LTV, LTI And DSR levels for each individual bank.

Table 4 reports the regression results for each re-run of the log-log specification of Column (3) of Table 2. Our estimates suggest that the aggregation level along which $C A$ is calculated does not dramatically change the picture: our elasticity estimates are between .12 and .17 for three of the tests, and rise to .23 when $C A$ is calculated while treating First-Time Buyers (FTB) and previousowners as separate market segments. The higher coefficient when FTB credit conditions are calculated differentially, combined with more liberalised credit conditions in the FTB market in Figure A.2 suggests that credit is more elastically passed through to house prices when it is made available to an FTB than a previous owner. This finding is intuitive as FTBs are, in the main, the marginal borrowers and are most sensitive to credit availability and down payment constraints in their house purchase activity (Engelhardt, 1994; Engelhardt and Mayer, 1998; Barakova et al., 2014). For the remainder of the paper, the coefficient estimates of the baseline model (2) of Table 2 will be imposed when assessing the role of macroprudential policy on the housing market.

Table 5 repeats the baseline model of Table 2, calculating all credit conditions at the 99th, rather 
Table 5: Repeat of Table 2, using 99th percentile credit conditions

\begin{tabular}{|c|c|c|c|}
\hline & $\begin{array}{c}(1) \\
\text { Level }\end{array}$ & $\begin{array}{c}(2) \\
\text { Level }\end{array}$ & $\begin{array}{c}\text { (3) } \\
\text { Log }\end{array}$ \\
\hline Credit Available & $\begin{array}{c}0.204^{* * *} \\
(0.00576)\end{array}$ & $\begin{array}{c}0.220^{* * *} \\
(0.00608)\end{array}$ & \\
\hline Income & $\begin{array}{l}0.784^{* * *} \\
(0.0337)\end{array}$ & $\begin{array}{l}0.571^{* * *} \\
(0.0356)\end{array}$ & \\
\hline Deposit & $\begin{array}{c}0.726^{* * *} \\
(0.00197)\end{array}$ & & \\
\hline Borrower Age & $\begin{array}{c}-637.6^{* * *} \\
(24.59)\end{array}$ & $\begin{array}{c}-801.2^{* * *} \\
(26.38)\end{array}$ & $\begin{array}{r}-0.00291^{* * *} \\
(0.000100)\end{array}$ \\
\hline Wealth for Down-Payment & & $\begin{array}{c}0.760^{* * *} \\
(0.00222)\end{array}$ & \\
\hline Log Credit Available & & & $\begin{array}{c}0.178^{* * *} \\
(0.00820)\end{array}$ \\
\hline Log Income & & & $\begin{array}{c}0.204^{* * *} \\
(0.00747)\end{array}$ \\
\hline Log Wealth for Down-Payment & & & $\begin{array}{c}0.245^{* * *} \\
(0.000852)\end{array}$ \\
\hline Observations & 188144 & 188144 & 188144 \\
\hline$R^{2}$ & 0.754 & 0.725 & 0.666 \\
\hline 4 Bank dummies? & YES & YES & YES \\
\hline 256 RegionTime dummies? & YES & YES & YES \\
\hline 8 property type dummies? & YES & YES & YES \\
\hline
\end{tabular}

than 98th percentile. This specification, accounting for more extreme values of the observed LTV, LTI and DSR distributions should be expected to increase the estimated impact of $C A$ on house prices. The points estimates across each model for $C A$, income and wealth are all extremely stable relative to those in Table 2. Our key result, the elasticity of house prices to $C A$ in Column (3), increases marginally from 15.5 per cent in the baseline model to 17.8 per cent when the 99th percentile of LTV, LTI and DSR are used to calculate $C A$.

\section{Measuring the impact of macroprudential policies}

Having established a relationship between credit availability and house prices, we can now test how the introduction of macroprudential policies can impact house prices through the credit channel. In this section, we outline scenarios for limits to LTI, LTV ratios and DSR informed by international experience and trace the impact of these through to house prices. 
Table 6: Macroprudential limits imposed under two sample regimes

\begin{tabular}{lrr}
\hline \hline & Regime 1 & Regime 2 \\
\hline LTV & 75 & 85 \\
LTI & 4 & 4.5 \\
DSR & $37 \%$ & $45 \%$ \\
\hline
\end{tabular}

\subsection{Macroprudential policy scenarios}

Our methodology allows the imposition of any combination of LTV, LTI and DSR limits that the researcher wishes to test. For brevity, we impose two sample regimes which are described in Table 6. Regime 1 is the more restrictive regime, where macroprudential limits are set at the high range of values reported across six economies by Jacome and Mitra (2015). Regime 2 imposes less restrictive limits. We refrain from imposing a regime that combines the most restrictive limits reported in Jacome and Mitra (2015) as we deem it implausible for political reasons that such a combination would ever be imposed without a long lead-in period. In both regimes, LTV, LTI and DSR values are significantly below those that were available in Ireland during the sample period, as reported in Figures 2, 3 and 5.

In Figure 7, we illustrate the impact of the two scenario macroprudential regimes on the way in which $C A$ is determined for Irish borrowers between 2003 and 2010. The first key take-away message from Figure 7 is that, across both regimes, income-related restrictions appear to have far more of an impact than down-payment constraints. In Figure 7a, the LTV limit of 80 per cent is the determining factor for less than 20 per cent of borrowers across the 2003-2010 period. In the less restrictive regime in Figure 7b, the LTV limit of 90 has even less of an effect in determining $C A$.

The differing importance of the DSR limits across time is driven by either (i) changes in the prevailing interest rate or (ii) changes in the age profile of borrowers, or (iii) differing bank policies on the maximum borrower age at maturity. The timing of the increase in importance of the DSR between 2006 and 2008, when mortgage interest rates rose by 200 basis points over a two year period suggests that the interest rate channel is the more important of the above factors.

\subsection{Re-fitting the house price series}

We utilise the coefficient estimates of Column (2) of Table 2 to re-fit house price values under the proposed MPP regimes. The way in which $C A$ is constructed in our framework allows for an extremely granular pass-through from a policy shift to $C A$. For every individual household obtaining a mortgage, a restriction on LTV, LTI or DSR will lead to a new calculation of the three loan amounts available, and a new estimate of $C A$. This new value of $C A$ can then be used to fit a new distribution of house prices in period $t$. The change in average house prices under the scenario impacts the size of deposit available to non-FTB borrowers (who are assumed to post down-payments as a function of 


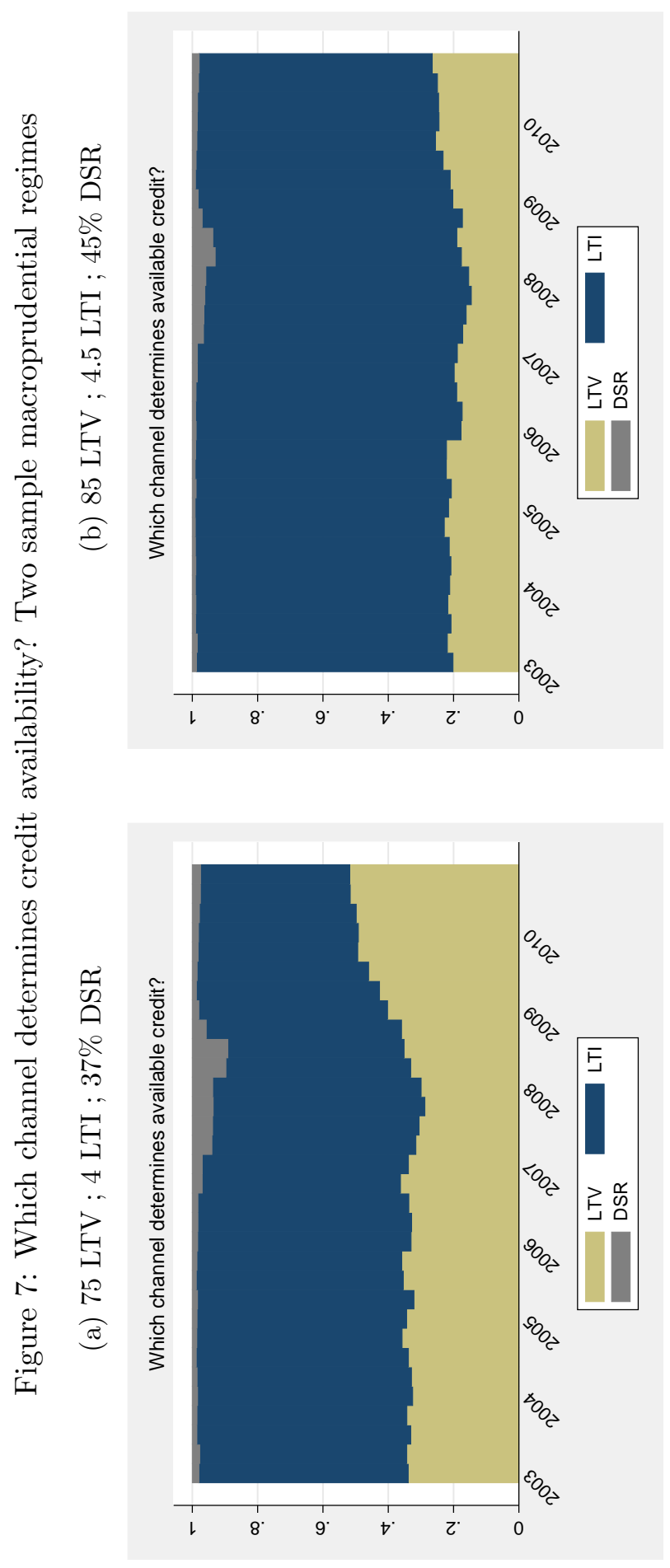


their housing equity), which means that $C A$ effects next-period house prices through a second channel, $\beta_{W e a l t h, t}$.

We are acutely aware of the limitations of such an approach, in that the counterfactual house price calculation using the coefficients of a reduced-form OLS regression merely fits a new house price to each borrower who purchased a property at a given point in time. There are a number of important long-run features that cannot be incorporated into our framework: (i) the exclusion of borrowers from the housing market, as we must assume that all borrowers simply access a cheaper house or the same house at a cheaper price, (ii) delayed house purchase due to the need for larger down-payments, (iii) a supply response to reductions in house prices (iv) increases in rents as a result of reduced access to owner-occupied housing, and the subsequent entry of Buy-to-Let investors in response to increased rental yields (v) general equilibrium effects such as the feedback loop between housing activity and incomes. For these reasons, we do not begin with the introduction of an MPP regime in period 1, and allow the model to estimate a counterfactual house price series for all periods. Rather, we restrict our exercise to the short run, where we assume that the above factors (i) to (v) may not have begun to take hold and influence house prices.

The most tractable way to estimate short-run effects in our framework is to iteratively cycle through the time periods in the data, starting with observed house prices in period $t$, switching on the MPP regime at $t$ and allowing our model to estimate the cumulative impact of the regime on house prices up to period $(t+4)$ (our data are quarterly). This allows us to estimate one-year effects of MPP regimes on house prices. We believe that one year is a reasonable approximation of the "short run", beyond which readers may worry that general equilibrium effects such as those mentioned in the previous paragraph become particularly relevant. The methodology is outlined more formally as follows:

In period $t$, fitted house prices are calculated as in equation 7 , where the coefficients of our baseline model are applied to observed data on our non-varying explanatory variables $X_{t}$ (income, property types, borrower age, region*time dummies), credit available $C A_{t}$ and Wealth .

$$
\hat{H P}{ }_{t}=X_{i t} \beta_{X}+\text { Wealth }{ }_{i t} \beta_{W e a l t h}+C A_{i t} \beta_{C A}
$$

The model then dynamically cycles through periods $t+1$ to $t+4$, retaining all coefficient estimates $\beta$ and values of the non-varying $X_{i t}$ from the baseline model as fixed. The updating procedure for Wealth $h_{i t}$ and $C A_{i t}$ at period $\mathrm{t}+1$ is as follows: the average of the fitted house prices from the previous period $\overline{H P}{ }_{t}$ is updated, and its ratio to house prices in the observed data is calculated. Our estimate of the wealth available for down-payments is then updated to reflect the differential between house prices at point $t$ in the scenario, and average house prices in the data at period $t$ (Equation 9). This adjustment allows borrowers in our counterfactual scenario to be impacted by housing equity changes 
due to MPP when placing a deposit with their house purchase. Such an interaction between housing collateral and house purchase price allows the logic of collateral channel models in the spirit of Kiyotaki and Moore (1997) to be incorporated into the model.

Given that our wealth estimate $W e a l t h_{t+1}$ is updated to reflect model-derived housing values from period t, $C A_{t+1}$ must now be updated to reflect these new deposit values. This involves a new calculation of $\operatorname{Loan}_{L T V}$, the loan commensurate with the borrower's wealth and prevailing LTVs offered in the market at period $\mathrm{t}+1$ (Equation 10). Once a new $C A_{t+1}$ is calculated (Equation 11), the model is now in a position to fit values for the house price distribution of borrowers in period $t+1$, $\hat{H P} P_{t+1}$ (Equation 12). The average of these new fitted values becomes $\bar{H} P_{t+1}$, which is then inputted as the lagged house price value for a full replication of the above steps at period $t+2$. This dynamic updating process continues until period $t+4$, giving an estimate of the average house price one year after the introduction of an MPP regime in Equation 18.

$$
\begin{aligned}
& \overline{H P} P_{t}=\operatorname{mean}\left(\hat{H P} P_{t}\right) \\
& \text { Wealth }_{t+1}={\frac{\overline{H P}}{\bar{H} P_{t} \text { data }}}^{*} \text { Wealth } h_{t+1, \text { data }} \\
& \operatorname{Loan}_{L T V t+1}=\frac{\text { Wealth }_{t+1}}{100-L T V_{M a x}}-\text { Wealth }_{t+1} \\
& C A_{t+1}=\operatorname{Min}\left(\operatorname{Loan}_{L T V, t+1}, \operatorname{Loan}_{L T I}, \operatorname{Loan}_{D S R}\right) \\
& \hat{H P} P_{M P, t+1}=X_{t+1} \beta_{X}+\text { Wealth } h_{t+1} \beta_{W e a l t h}+C A_{t+1} \beta C A \\
& \bar{H} P_{t+3}=\operatorname{mean}\left(\hat{H} P_{M P, t+3}\right) \\
& \text { Wealth }_{t+3}={\frac{\bar{H} P_{t+3}}{H P_{t+3, \text { data }}}}^{*} \text { Wealth }_{t+3, \text { data }} \\
& \operatorname{Loan}_{L T V, t+4}=\frac{\text { Wealth }}{t+4}-\text { Wealth }_{t+4} \\
& C A_{t+4}=\operatorname{Min}\left(\operatorname{Loan}_{L T V, t+4}, \operatorname{Loan}_{L T I}, \operatorname{Loan}_{D S R}\right) \\
& \hat{H P}{ }_{M P, t+4}=X_{t+4} \beta_{X}+\text { Wealth }{ }_{t+4} \beta_{W \text { ealth }}+C A_{t+4} \beta_{C A}
\end{aligned}
$$

As well as our main objective of testing how restrictions across LTV, LTI and DSR impact house prices, we can also test a secondary hypothesis relating to the timing of the measures being introduced. What matters for the impact of such policies is how they deviate from the current credit conditions in the market. If MPP restricted levels are similar to current credit conditions, less of an impact on the housing market will be expected. For example, turning strict macroprudential loan restrictions on in a period of very loose market credit conditions will potentially have a larger impact on credit flows 
and subsequently house prices than in a period of tighter credit conditions.

To illustrate how such differential impacts, we "turn on" our macroprudential scenarios at two points in our data: 1) where market credit conditions were tighter (earlier in the Irish credit cycle) and 2) where credit conditions were looser (at the peak of the Irish credit boom). In practical terms, we turn on the two scenarios outlined in Table 6 in each quarter for the years 2003 (tighter market conditions) and 2006 (looser market conditions), iterate the one year impact for each quarter and take the mean across the four quarters. This provides an estimate of the impact on house prices of turning on the measures at any time during the years 2003 and 2006. The results are presented in table 7.

Table 7: Impact of macroprudential limits on house prices

\begin{tabular}{lcc}
\hline \hline & $\begin{array}{c}\text { Regime 1: Tighter MPP } \\
\text { (75 LTV, 4 LTI, 37\% DSR) }\end{array}$ & $\begin{array}{c}\text { Regime 2: Looser MPP } \\
\text { (85 LTV, 4.5 LTI, 45\% DSR) }\end{array}$ \\
\hline Timing & \multicolumn{3}{c}{ House Price Changes } \\
\hline Tighter Market Credit (2003): & $-6.4 \%$ & $-1.2 \%$ \\
Looser Market Credit (2006): & $-12.1 \%$ & $-8.7 \%$ \\
\hline \hline
\end{tabular}

Intuitively, the one-year impact on house prices is largest in the more restrictive MPP regime. The model estimates that the switching on of Regime 1 (75 LTV, 4 LTI and 37 DSR) in 2003 would have led to a fall in average house prices from observed levels of 6.4 per cent after four quarters. During the high-growth period of 2006, this MPP regime would have led to one-year falls of 12.1 per cent. Our less restrictive MPP regime, Regime 2 (85 LTV, 4.5 LTI and 45 DSR) is estimated to have a one-year effect of 1.2 per cent when switched on in 2003, with this effect rising to 8.7 per cent when switched on in 2006 .

Table 7 confirms that the timing of MPP matters hugely. For a given combination of LTV and LTI, there are much larger effects felt as the cycle moves towards its peak. This suggests that it may be beneficial to introduce MPP regimes away from the peak of the housing cycle, to avoid large shocks to asset markets. Once introduced in a period of weak house price growth, an MPP regime may act to bolster borrower and lender resilience against future shocks, without dramatic impacts on housing values.

The magnitude impacts of varying combinations of LTV and LTI restrictions are presented through a heatmap. For brevity, we also present the effects for turning the model on in two specific quarters (Q1 2003 and Q3 2006). Figure 8 presents results from thirty-six versions of our model, where combinations of six distinct LTV and LTI limits are imposed at 2006q3 and 2003q $1,{ }^{8}$ with the DSR set at the market limit as per Figure 5. The left-hand panel shows for Q3 2006, as expected, that larger house price falls are found at stricter joint values of LTV and LTI, with the house price impact at an LTV of 70 and

\footnotetext{
${ }^{8}$ This is the period with the largest amount of originated mortgages.
} 
LTI of 2.8 being over 20 per cent, while the impact at an LTV of 95 and an LTI of 4.5 being under 10 per cent. Of note is the symmetry of the effects: movements from the top-right (loose conditions) towards the bottom-left (tight conditions) appear to have similar impacts regardless of whether LTV or LTI is relatively tighter. The only noticeable asymmetry is at extreme values: when LTI is fixed at 2.8, loosening LTV limits from 75 through to 95 has close to no impact on house prices, suggesting that an LTI limit of 2.8 acts as an extremely hard limit. On the other hand, when LTV is set at 70, a loosening of LTI from 2.8 to 4.5 does lead to some easing in the impact of the policy regime on house prices.

The right-hand panel of Figure 8 shows house price changes from an MPP regime switched on in 2003q1. As would be expected given that this period is much earlier in the Irish housing boom period, the magnitude of house price impacts for a given LTV-LTI combination is much smaller. However, the substantive patterns in the data remain the same when viewed from this different starting point. An intuitive take-away from these images is that the expected impact of MPP regimes on the housing market varies as a function of the point in the housing cycle in which they are implemented. 


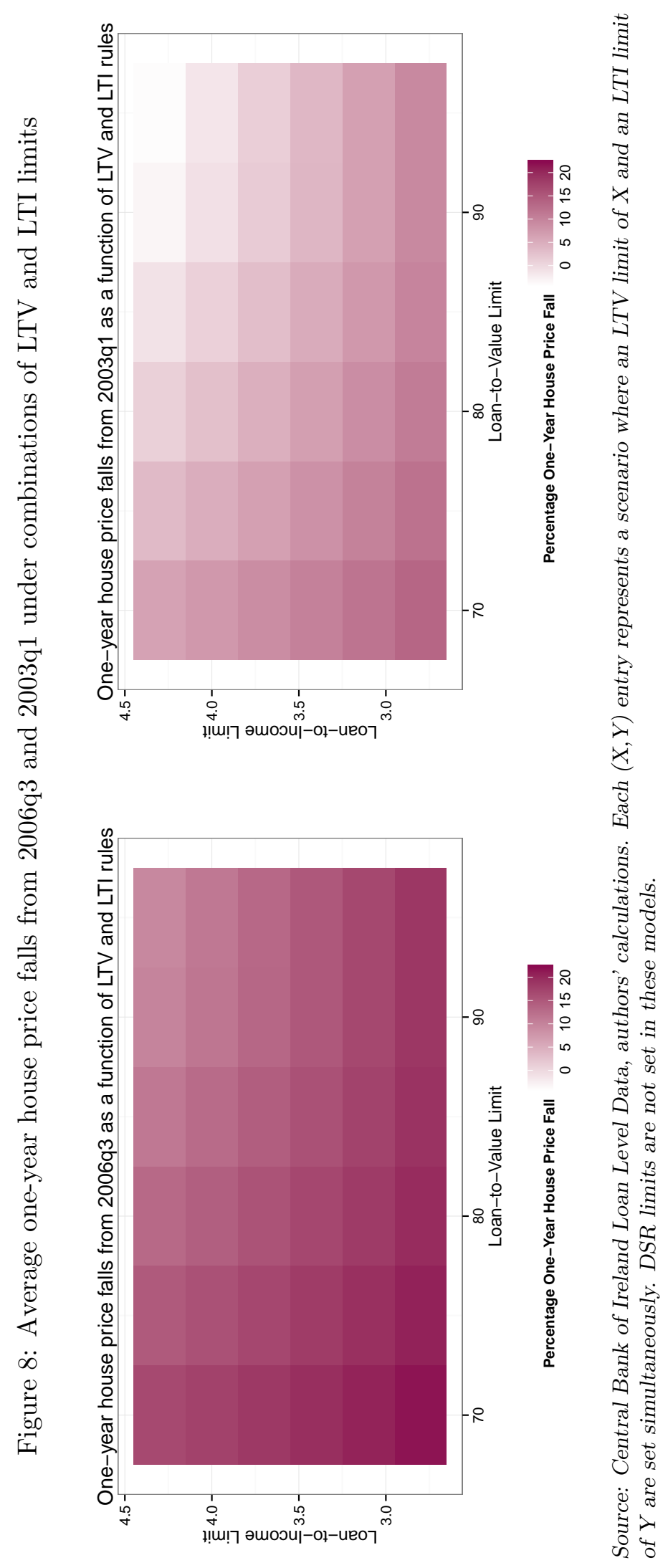




\section{Conclusion}

The link between macroprudential policy, credit allocation and the housing market is one of crucial importance to economic and financial stability. In this paper we present a novel measure of credit available at the loan level, where we model the way in which credit supply can bind along three channels: the Loan to Value ratio (LTV), the Loan to Income ratio (LTI) and the Debt Service Ratio (DSR). Using prevailing market conditions on the level of originating LTV, LTI and DSR available in a given quarter, we construct three possible loan amounts for each borrower, commensurate with their income, deposit and age. The credit available to a borrower is calculated as the smallest of these three loans.

We show initially that in Ireland between 2003 and 2010, the majority of borrowers had their credit availability determined by the prevailing LTI ratio, with extremely small numbers of borrowers being cut off along the LTV channel due to the existence of 100 per cent LTV mortgages.

Using our constructed measure of credit availability, we run a property-level house price model on 190,000 mortgaged house purchases, where the transaction price is a function of credit, incomes, deposits, a dummy variable for the lending institution, hedonic property characteristics as well as a range of national and regional macroeconomic factors. In our baseline scenario, the elasticity of house prices with respect to credit availability is found to be approximately 0.15 , which is extremely close to estimates from Favara and Imbs (2015). Our micro-level house price model also estimates that a ten per cent increase in income increases house prices by between 2.1 and 2.6 per cent while a ten per cent increase in wealth increases house prices by 2.4-2.5 per cent.

Our methodology allows us to directly model the link between MPP and each borrower's credit availability in a granular fashion. MPP drives house price changes in two ways: firstly through the direct impact of instantaneously lower credit volumes; secondly through the collateral channel, by scaling down the down-payment available to borrowers via weakened housing equity. We fit values using our regression coefficients and restricted credit for four quarters after the introduction of the MPP regime, due to the fact that our exercise cannot account for general equilibrium relationships between lower house prices and housing supply, rents, Buy to Let purchases or construction sector and related incomes.

Our findings imply an important role for MPP in cooling a rapidly-growing housing market. Further they suggest that the levels at which LTV, LTI and DSR limits are set are crucially important in determining the impact on prices. We show that the introduction of an LTV-LTI combination of 70 and 2.8 leads to a house price fall two and a half times as large as a combination of 95 and 4.5 . Further, we highlight the importance of the timing of the introduction of an MPP regime: estimates of the impact on house prices are orders of magnitude larger for regimes switched on in 2006, at the 
top of the Irish housing cycle, versus 2003.

We believe that our paper is the first to treat the relationship between MPP, mortgage credit and house prices at such a granular level of detail, and the first to quantitatively estimate the impact of MPP scenarios on house price paths. Further research is warranted on the general equilibrium effects that follow on from the introduction of an MPP, particularly relating to borrower exclusion, housing supply and the rental market.

\section{References}

Adelino, Manuel, Antoinette Schoar, and Felipe Severino, "Credit Supply and House Prices: Evidence from Mortgage Market Segmentation," NBER Working Papers 17832, National Bureau of Economic Research, Inc February 2012.

Akram, Q. Farooq, "Macro effects of capital requirements and macroprudential policy," Economic Modelling, 2014, 42 (C), 77-93.

Allen, Jason, Robert Clark, and Jean-Francois Houde, "Macroprudential housing policies and borrowing constraints," Mimeo, Bank of Canada Oct 2015.

Anenberg, Elliot, Aurel Hizmo, Edward Kung, and Raven Molloy, "The Effect of Mortgage Credit Availability on House Prices and Construction: Evidence from a Frontier Estimation Approach," Mimeo, Board of Governors of the Federal Reserve System Nov 2015.

Anundsen, Andr K. and Eilev S. Jansen, "Self-reinforcing effects between housing prices and credit," Journal of Housing Economics, 2013, 22 (3), 192-212.

Avouyi-Dovi, S., C. Labonne, and R. Lecat, "The housing market: the impact of macroprudential measures in France," Financial Stability Review, April 2014, (18), 195-206.

Bailliu, Jeannine, Csaire Meh, and Yahong Zhang, "Macroprudential Rules and Monetary Policy when Financial Frictions Matter," Economic Modelling, 2015, 50, 148-161.

Barakova, Irina, Paul S. Calem, and Susan Wachter, "Borrowing constraints during the housing bubble," Journal of Housing Economics, 2014, 24 (C), 4-20.

Brunnermeier, Markus, "Deciphering the Liquidity and Credit Crunch 2007-2008," Journal of Economic Perspectives, 2009, 23 (1), 77-100.

Brzoza-Brzezina, Michal, "Financial Frictions and Macroprudential Policy," International Journal of Central Banking, 2014, 10 (2), 249-261. 
- and Marcin Kolasa, "Bayesian evaluation of DSGE models with financial frictions," Working Papers 71, Department of Applied Econometrics, Warsaw School of Economics 2013.

_ , _ , and Krzysztof Makarski, "Macroprudential policy and imbalances in the euro area," Journal of International Money and Finance, 2015, 51 (C), 137-154.

Cerutti, Eugenio, Stijn Claessens, and Luc Laeven, "The use and effectiveness of macroprudential policies: new evidence," Working Paper WP/15/61, International Monetary Fund 2015.

Claessens, Stijn, Swati R. Ghosh, and Roxana Mihet, "Macro-prudential policies to mitigate financial system vulnerabilities," Journal of International Money and Finance, 2013, 39 (C), 153185.

Clancy, Daragh and Rossana Merola, "The effect of macroprudential policy on endogenous credit cycles," Research Technical Papers 15/RT/14, Central Bank of Ireland November 2014.

Duca, John, John Muellbauer, and Anthony Murphy, "Housing markets and the financial crisis of 2007-2009: Lessons for the future," Journal of Financial Stability, 2010, 6 (4), 203-217.

Duca, John V., John Muellbauer, and Anthony Murphy, "House Prices and Credit Constraints: Making Sense of the US Experience," Economic Journal, 2011, 121 (552), 533-551.

$\ldots, \ldots$, and _ , "House Prices and Credit Constraints: Making Sense of the US Experience," Economic Journal, 05 2011, 121 (552), 533-551.

Elul, Ronel, Nicholas Souleles, Souphala Chomsisengphet, Dennis Glennon, and Robert Hunt, "What "Triggers" Mortgage Default?," American Economic Review, 2010, 100 (2), 490-94.

Engelhardt, Gary, "House Prices and the Decision to Save for Down Payments," Journal of Urban Economics, 1994, 36 (2), 209-237.

Engelhardt, Gary V. and Christopher Mayer, "Intergenerational Transfers, Borrowing Constraints, and Saving Behavior: Evidence from the Housing Market," Journal of Urban Economics, 1998, 44 (1), 135-157.

Favara, Giovanni and Jean Imbs, "Credit Supply and the Price of Housing," American Economic Review, March 2015, 105 (3), 958-92.

Fernandez-Corugedo, Emilio and John Muellbauer, "Consumer credit conditions in the United Kingdom," Working Paper 314, Bank of England 2006. 
Fitzpatrick, Trevor and Kieran Mcquinn, "House Prices And Mortgage Credit: Empirical Evidence For Ireland," Manchester School, 01 2007, 75 (1), 82-103.

Gerali, Andrea, Stefano Neri, Luca Sessa, and Federico Signoretti, "Credit and Banking in a DSGE Model of the Euro Area," Journal of Money, Credit and Banking, 2010, 42 (s1), 107-141.

Gerlach, Stefan and Wensheng Peng, "Bank lending and property prices in Hong Kong," Journal of Banking \& Finance, 2005, 29 (2), 461-481.

Igan, Deniz and Heedon Kang, "Do Loan-To-Value and Debt-To-Income Limits Work? Evidence From Korea," IMF Working Papers 11/297, International Monetary Fund December 2011.

IMF, "Key Aspects of Macro-prudential Policy," Background Paper, IMF 2013.

International Monetary Fund, "Macroprudential Policy; What Instruments and How to Use them? Lessons From Country Experiences," IMF Working Papers 11/238, International Monetary Fund October 2011.

Jacome, Luis and Srobona Mitra, "LTV and DTI Limits - Going Granular," Working Paper WP/15/154, International Monetary Fund 2015.

Jansen, Eilev S. and Tord S. H. Krogh, "Credit conditions indices: Controlling for regime shifts in the Norwegian credit market," Discussion Papers 646, Research Department of Statistics Norway February 2011.

Kannan, Prakash, Pau Rabanal, and Scott Alasdair M., "Monetary and Macroprudential Policy Rules in a Model with House Price Booms," The B.E. Journal of Macroeconomics, 2012, 12 (1), 1-44.

Kashyap, Anil K, Richard Berner, and Charles A E Goodhart, "The Macroprudential Toolkit," IMF Economic Review, 2011, 59 (2), 145-161.

Kennedy, Gerard and Tara McIndoe-Calder, "The Irish Mortgage Market: Stylised Facts, Negative Equity and Arrears," Quarterly Bulletin Articles, February 2012, pp. 85-108.

Kiyotaki, Nobuhiro and John Moore, "Credit Cycles," Journal of Political Economy, 1997, 105 (2), pp. 211-248.

Kuttner, Kenneth $\mathbf{N}$ and Ilhyock Shim, "Can non-interest rate policies stabilise housing markets? Evidence from a panel of 57 economies," BIS Working Papers 433, Bank for International Settlements November 2013. 
Labonne, Claire and Cécile Welter-Nicol, "Cheap Credit, Expensive Houses?," Mimeo, ACPR Banque de France 2015.

Lindner, Fabian, "The Interaction of Mortgage Credit and Housing Prices in the US," IMK Working Paper 133-2014, IMK at the Hans Boeckler Foundation, Macroeconomic Policy Institute 2014.

Maggio, Marco Di and Amir Kermani, "Credit-Induced Boom and Bust," Research Paper 14-23, Columbia Business School December 2014.

McCarthy, Yvonne and Kieran McQuinn, "Credit conditions in a boom and bust property market," Research Technical Papers 08/RT/13, Central Bank of Ireland October 2013.

Mian, Atif and Amir Sufi, "The Consequences of Mortgage Credit Expansion: Evidence from the U.S. Mortgage Default Crisis," The Quarterly Journal of Economics, 2009, 124 (4), 1449-1496.

Quint, Dominic and Pau Rabanal, "Monetary and Macroprudential Policy in an Estimated DSGE Model of the Euro Area," International Journal of Central Banking, 2014, 10 (2), 169-236.

Rubio, Margarita and Jos Carrasco-Gallego, "Macroprudential and monetary policies: Implications for financial stability and welfare," Journal of Banking $\mathcal{E}$ Finance, 2014, 49 (C), 326-336.

Vandenbussche, Jerome, Ursula Vogel, and Enrica Detragiache, "Macroprudential Policies and Housing Prices: A new database and empirical evidence for Central, Eastern and Southerstern Europe," Journal of Money, Credit and Banking, March-April 2015, 47 (1), 343-377.

Wong, Eric, Tom Fong, Ka Fai Li, and Henry Choi, "Loan-to-Value Ratio as a Macro-Prudential Tool - Hong Kong's Experience and Cross-Country Evidence," Working Papers 1101, Hong Kong Monetary Authority 2011.

\section{Appendix}




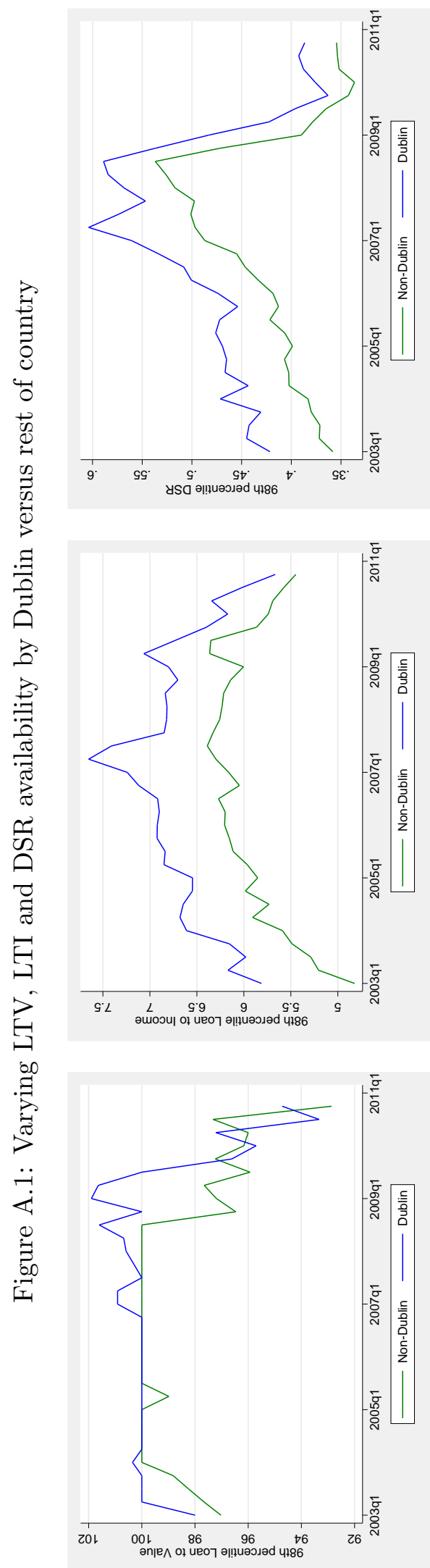




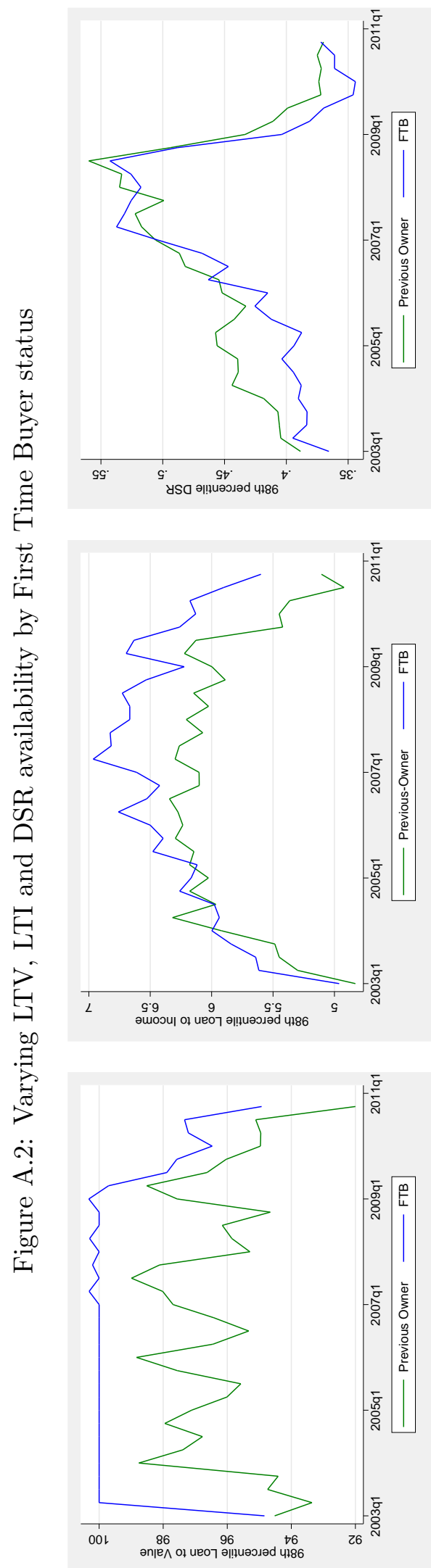




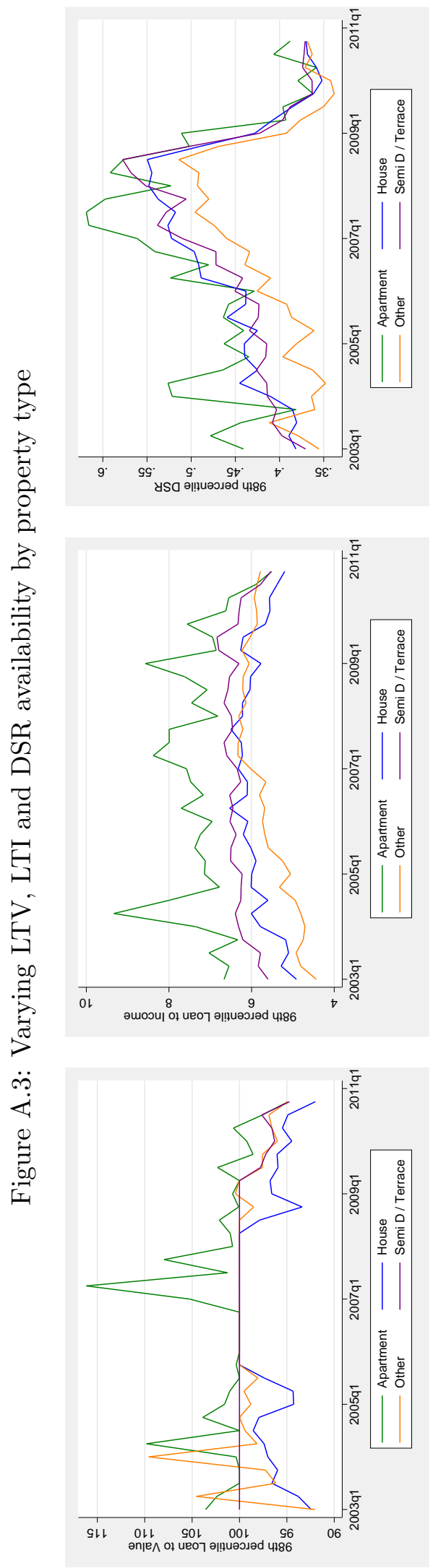

